\title{
Phenotypes of allergic diseases in children and their application in clinical situations
}

\author{
Eun Lee, MD, PhD', Soo-Jong Hong, MD, PhD² \\ ${ }^{1}$ Department of Pediatrics, Chonnam National University Hospital, Chonnam National University Medical School, Gwangju, ${ }^{2}$ Department of Pediatrics, Childhood \\ Asthma Atopy Center, Environmental Health Center, Asan Medical Center, University of Ulsan College of Medicine, Seoul, Korea
}

Allergic diseases, including allergic rhinitis, asthma, and atopic dermatitis, are common heterogeneous diseases that encompass diverse phenotypes and different pathogeneses. Phenotype studies of allergic diseases can facilitate the identification of risk factors and their underlying pathophysiology, resulting in the application of more effective treatment, selection of better treatment responses, and prediction of prognosis for each phenotype. In the early phase of phenotype studies in allergic diseases, artificial classifications were usually performed based on clinical features, such as triggering factors or the presence of atopy, which can result in the biased classification of phenotypes and limit the characterization of heterogeneous allergic diseases. Subsequent phenotype studies have suggested more diverse phenotypes for each allergic disease using relatively unbiased statistical methods, such as cluster analysis or latent class analysis. The classifications of phenotypes in allergic diseases may overlap or be unstable over time due to their complex interactions with genetic and encountered environmental factors during the illness, which may affect the disease course and pathophysiology. In this review, diverse phenotype classifications of allergic diseases, including atopic dermatitis, asthma, and wheezing in children, allergic rhinitis, and atopy, are described. The review also discusses the applications of the results obtained from phenotype studies performed in other countries to Korean children. Consideration of changes in the characteristics of each phenotype over time in an individual's lifespan is needed in future studies.

Key words: Allergic diseases, Child, Phenotype, Sensitization

\section{Graphical Abstract}

\section{Phenotypes of allergic disease}

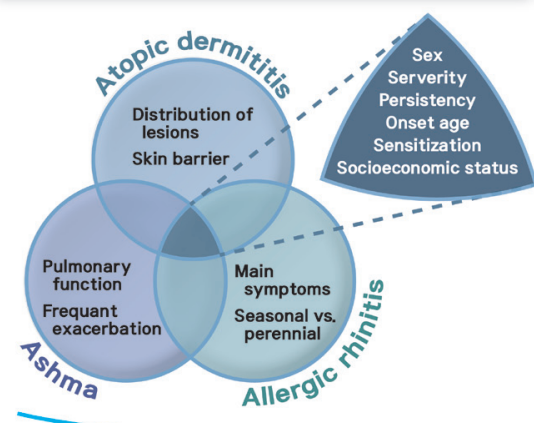

Endotypes of allergic disease

Genetic \& epigenetic factors

Innate \& adaptive responses

Metabolic pathways

Exposome (allergen, pollutants, irritants)
Corresponding author: Soo-Jong Hong, MD, PhD Department of Pediatrics, Childhood Asthma Atopy Center, Environmental Health Center, Asan Medical Center, University of Ulsan College of Medicine, 88 Olympic-ro 43 gil, Songpa-gu, Seoul 05505, Korea Tel: +82-2-3010-3379

Fax: $+82-2-473-3725$

E-mail: sjhong@amc.seoul.kr

https://orcid.org/0000-0003-1409-2113

Received: 31 December, 2018

Revised: 7 April, 2019

Accepted: 18 April, 2019

\section{Copyright (c) 2019 by The Korean Pediatric Society}

This is an open-access article distributed under the terms of the Creative Commons Attribution NonCommercial License (http://creativecommons.org/ licenses/by-nc/4.0/) which permits unrestricted noncommercial use, distribution, and reproduction in any medium, provided the original work is properly cited.

Factors that affect phenotypes and endotypes of allergic diseases in children. 


\section{Introduction}

Diverse allergic diseases, including atopic dermatitis (AD), asthma, and allergic rhinitis (AR), develop as a result of complex interactions between genetic and environmental factors. In the early era, phenotypes were artificially classified based on clinical course or chief symptoms without considering the pathophysiology of the underlying heterogeneous manifestations of allergic diseases. The recent advent of diverse cluster analysis methods, which allows complex simultaneous considerations of genetic factors, long-term clinical course, and prognosis, has contributed to the identification of more diverse phenotypes of allergic diseases (Tables 1-4). Diverse studies of the phenotypes of allergic diseases, combined with the underlying endotypes encompassing all available biomarkers, have contributed to better identification of the pathophysiology of each disease and development of treatment strategies and biologics specifically applicable to each disease phenotype. ${ }^{1 .}$ Therefore, the previous concept of "one size fits all" is being replaced by the concept of "personalized medicine."

Phenotype classification may overlap or crossover with other phenotypes during long-term follow-up. A clear-cut classification of phenotypes in allergic diseases might be impossible due to the common pathways underlying the diseases. Nevertheless, phenotype studies of allergic diseases may contribute to better understanding of the underlying pathophysiology, thereby enabling the development of personalized therapies against these diseases. ${ }^{2)}$

Considering endophenotypes, defined as a biological phenomenon in the causal chain between genotype and related symptoms, ${ }^{3)}$ might better explain the complex and heterogeneous allergic diseases and, therefore, be usefully applied in clinical practice. A comprehensive approach considering the diverse environmental factors and characteristic diverse clinical symptoms combined with characteristic pathophysiologies might be the target of personalized medicine for individuals with differing genetic backgrounds and would be helpful in identifying and understanding the heterogeneous phenotypes of allergic diseases. Here we summarize the results of phenotype studies on diverse allergic diseases and atopy in children that are usually subjected to unbiased phenotype classifications, ${ }^{4)}$ especially during long-term follow-up, and suggest directions for related future research.

Table 1. Summary of representative phenotype studies of atopic dermatitis

\begin{tabular}{|c|c|c|c|c|c|c|}
\hline Study & $\begin{array}{l}\text { Subject } \\
\text { number }\end{array}$ & $\begin{array}{l}\text { Methods of } \\
\text { phenotype } \\
\text { classification }\end{array}$ & $\begin{array}{l}\text { No. of } \\
\text { groups }\end{array}$ & Differential features & Phenotypes & Main findings \\
\hline $\begin{array}{c}\text { Seo et al. }{ }^{18)} \\
(2019)\end{array}$ & 572 & $\begin{array}{l}\text { Hierarchical cluster } \\
\text { analysis using } \\
\text { Ward's, methods }\end{array}$ & 4 & $\begin{array}{l}\text { Onset age, age at diag- } \\
\text { nosis, total serum lgE } \\
\text { levels, WBC count, } \\
\text { blood eosinophils }\end{array}$ & $\begin{array}{l}\text { 1. Early-onset, high blood eosinophil counts, total serum } \\
\text { IgE, and rates of sensitization to food allergens } \\
\text { 2. Early-onset, low blood eosinophil counts, tota serum } \\
\text { IgE and rates of sensitization to both food and inhalant } \\
\text { allergens } \\
\text { 3. Early-onset, high CRP levels and WBC counts } \\
\text { 4. Middle-onset, high total serum IgE levels, and rates of } \\
\text { sensitization to inhalant allergens }\end{array}$ & $\begin{array}{l}\text { The presence of heterogeneity } \\
\text { of } A D \text {, even in early childhood }\end{array}$ \\
\hline $\begin{array}{l}\text { Paternoster } \\
\text { et al. }^{12)} \\
(2018)\end{array}$ & 9,894 & Longitudinal LCA & 6 & Onset age, persistence & $\begin{array}{l}\text { 1. Early-onset, persistent } \\
\text { 2. Early-onset, late-resolving } \\
\text { 3. Early-onset, early-resolving } \\
\text { 4. Mid-onset, resolving } \\
\text { 5. Late-onset, resolving } \\
\text { 6. Unaffected/transient }\end{array}$ & $\begin{array}{l}\text { The differing risk factors and } \\
\text { diverse prognoses according } \\
\text { to } A D \text { phenotypes suggest the } \\
\text { need for stratified medicine } \\
\text { approach }\end{array}$ \\
\hline $\begin{array}{l}\text { Roduit } \\
\text { et al. }^{16)} \\
\text { (2017) }\end{array}$ & 1,038 & LCA & 4 & $\begin{array}{l}\text { Onset age, disease } \\
\text { course }\end{array}$ & $\begin{array}{l}\text { 1. Early transient } \\
\text { 2. early persistent } \\
\text { 3. late phenotype with onset at age } 2 \text { years or older } \\
\text { 4. never/infrequent phenotype }\end{array}$ & $\begin{array}{l}\text { Prevalence of asthma \& food } \\
\text { allergy by } 6 \text { years of age is } \\
\text { strongly increased among } \\
\text { children with early phenotypes } \\
\text { (within age } 2 \text { years), especially } \\
\text { with persistent symptoms }\end{array}$ \\
\hline $\begin{array}{l}\text { Amat et } \\
\left.\text { al. }{ }^{15}\right) \\
(2015)\end{array}$ & 214 & $\begin{array}{l}\text { Hierarchical bot- } \\
\text { tom-up cluster- } \\
\text { ing }\end{array}$ & 3 & $\begin{array}{l}\text { Sensitizations, severity } \\
\text { of } A D\end{array}$ & $\begin{array}{l}\text { 1. AD with low sensitization: low to no sensitization and } \\
\text { moderate severity } \\
\text { 2. AD with multiple sensitizations: higher severity and } \\
\text { frequent sensitization to food or aeroallergens } \\
\text { 3. AD with familial history of asthma: with parental his- } \\
\text { tory, moderate severity, and moderate rate of sensi- } \\
\text { tization to food }\end{array}$ & $\begin{array}{l}\text { AD with multiple sensitizations } \\
\text { and } A D \text { with familial history of } \\
\text { asthma convey higher risks of } \\
\text { asthma during childhood }\end{array}$ \\
\hline $\begin{array}{l}\text { Lee et al. }{ }^{17)} \\
(2016)\end{array}$ & 242 & LCA & 4 & Onset age, persistence & $\begin{array}{l}\text { 1. Early-onset with low atopy } \\
\text { 2. Early-onset with high atopy and high eosinophil levels } \\
\text { 3. Late-onset with low atopy } \\
\text { 4. Late-onset with high atopy and normal eosinophil } \\
\text { levels }\end{array}$ & $\begin{array}{l}\text { Early-onset of AD with high } \\
\text { atopy and high eosinophil } \\
\text { levels is associated with } \\
\text { allergic march }\end{array}$ \\
\hline
\end{tabular}

AD, atopic dermatitis; CRP, C-reactive protein; lgE, immunoglobulin E; LCA, latent class analysis; WBC, whole blood count. 


\section{Phenotypes of $A D$ in children}

$\mathrm{AD}$ is characterized by a wide spectrum, from very mild forms of dryness with minimal eczema to severe forms with later development of other allergic diseases. Some cases of $\mathrm{AD}$ are characterized by remission with age, with recurrence after a considerable period in other cases. ${ }^{5}$ The diverse clinical courses of $\mathrm{AD}$ suggest the presence of diverse phenotypes according to the underlying pathophysiology. Predicting the clinical course at the time of AD diagnosis might help the planning of individualized treatment measures.

Classically, $\mathrm{AD}$ was divided into intrinsic and extrinsic forms. ${ }^{6}{ }^{6}$ The former is characterized by normal total serum immunoglobulin E (IgE) levels with nonatopy, while the latter is characterized by high total serum IgE levels with atopy. ${ }^{6}$ However, not only do the two forms of $\mathrm{AD}$ have common findings, such as clinical appearance, family history, disease duration, and serum levels of interleukin (IL)-5 and IL-13, ${ }^{7,8}$ the dichotomized classification is insufficient to explain the heterogeneous clinical courses, prognoses, and responses to specific treatment in children with $\mathrm{AD}$. $^{9)}$ Subsequent studies have introduced more diverse $\mathrm{AD}$ phenotypes, which are divided into 4-6 groups (Table 1).

The differentiating features in the classification of $\mathrm{AD}$ phenotypes include onset age, ${ }^{10-12)}$ severity, ${ }^{13)}$ treatment, ${ }^{14)}$ atopy, disease course (persistence or remission), skin barrier dysfunction, and biomarkers (blood eosinophil and total serum IgE) (Table 1). Since AD develops at a relatively young age compared with other allergic diseases, studies on $\mathrm{AD}$ phenotypes have attempted to identify its persistence and the later development of other allergic diseases in each phenotype ${ }^{15-17)}$ Multiple sensitizations, combined with high levels of total serum IgE and eosinophils, are commonly associated with the later development of asthma. ${ }^{15,17,18)}$ In addition, the onset age of $\mathrm{AD}$ combined with the presence of a food allergy is associated with asthma development in later life. ${ }^{16,17)}$ Since $\mathrm{AD}$ persistence affects the development of asthma and $\mathrm{AR},{ }^{19)}$ treatment adherence in $\mathrm{AD}$ impacts its control and clinical course ${ }^{20)}$ thus, adherence should be considered a strong predictor of cluster assignment in AD. However, no phenotype studies of $\mathrm{AD}$ have considered treatment adherence as a differential point.

Although a comprehensive concept that explains AD development has changed from complex but simple interactions between genetic and environmental factors to both skin barrier dysfunction and altered immune responses and their associated genetic background, ${ }^{9}$ phenotype studies including these factors are lacking. Genetic factors associated with skin barrier function include serine protease inhibitor Kazal-type 5 (SPINK5) and filaggrin, while those associated with immune regulation include subsets of Toll-like receptors and interleukin families. ${ }^{21-23)}$ Phenotype studies considering genetic susceptibility and explaining the differences underlying skin barrier dysfunction and altered immune regulation might better explain the pathophysiology of $\mathrm{AD}{ }^{24)}$
Since $\mathrm{AD}$ phenotypes might differ among ethnicities, ${ }^{24)}$ extrapolation of the identified $\mathrm{AD}$ phenotypes in foreign countries arouses concerns with regard to its application to Korean children. Considering the comprehensive factors associated with $\mathrm{AD}$, the identification of its phenotypes apposite to Korean children is needed to establish tailored prevention and therapeutic strategies.

\section{Phenotypes of asthma and wheezing in children}

Phenotype studies of allergic diseases have been most commonly performed in asthma and wheezing in children due to the high prevalence in early life. ${ }^{25)}$ Although the natural courses of asthma and wheezing episodes are quite heterogeneous, especially in preschool children, asthma was conventionally classified into 2 groups: extrinsic (allergic) and intrinsic (nonallergic). ${ }^{26)}$ This dichotomized classification implies important intergroup differences in pathophysiology, such as T-cell function and cytokine levels. ${ }^{27)}$ Subsequent studies of asthma and wheezing phenotypes have considered more diverse factors, such as onset age, triggers, persistence, severity, or pulmonary function levels using unbiased methods to better reflect the underlying pathophysiology, prognosis, and treatment response for classifying phenotypes (Table 2) ${ }^{28)}$

The first and widely used phenotypes of asthma and wheezing in children originated from the Tucson Children's Respiratory Study. ${ }^{28)}$ In that study, wheezing phenotypes were classified into 4 groups: never wheeze, early transient wheeze, persistent wheeze, and lateonset wheeze. Among these groups, children in the IgE-associated persistent wheeze and late-onset wheeze groups showed an increased risk of asthma. ${ }^{28)}$ The results were validated in children from other countries, including Italian children. ${ }^{29)}$ These wheezing phenotypes are very helpful for pediatricians predicting the risk of asthma in preschool children with wheezing.

Subsequent wheezing phenotype studies were performed in the Avon Longitudinal Study of Parents And Children (ALSPAC) and Prevention and Incidence of Asthma and Mite Allergy (PIAMA) studies on the basis of longitudinal data from birth to 8 years of age ${ }^{30,31)}$ In the ALSPAC study, wheezing in the preschool period was classified into 6 groups: never/infrequent wheeze, transient early wheeze, prolonged early wheeze, intermediate-onset wheeze, late-onset wheeze, and persistent wheeze. ${ }^{31)}$ In the PIAMA study, wheezing in early life was classified into 5 groups: never/infrequent wheeze, transient early wheeze, intermediate-onset wheeze, lateonset wheeze, and persistent wheeze. ${ }^{30)}$ The persistent wheeze phenotype showed an increased risk of asthma. These studies were significant in that their results suggested evidence for predicting asthma in preschool children with wheezing.

Efforts aimed at designing more sophisticated and diverse approaches to characterizing asthma phenotypes and endotypes have resulted in the identification of inflammatory phenotypes (eosino- 
Table 2. Summary of representative phenotype studies on asthma

\begin{tabular}{|c|c|c|c|c|c|c|}
\hline Study & $\begin{array}{l}\text { Subject } \\
\text { number }\end{array}$ & $\begin{array}{l}\text { Methods of } \\
\text { phenotype } \\
\text { classification }\end{array}$ & $\begin{array}{l}\text { No. of } \\
\text { groups }\end{array}$ & Differential features & Description of clusters & Main findings \\
\hline $\begin{array}{l}\text { Sendín-Hernández } \\
\text { et al al. }{ }^{36)}(2018)\end{array}$ & 225 & Cluster analysis & 3 & $\begin{array}{l}\text { Family history, onset } \\
\text { age, severity of as- } \\
\text { thma }\end{array}$ & $\begin{array}{l}\text { 1. Intermittent or mild persistent asthma, without } \\
\text { family antecedents of atopy, asthma, or rhinitis } \\
\text { 2. Mild asthma with a family history of atopy, } \\
\text { asthma, or rhinitis } \\
\text { 3. Moderate or severe persistent asthma that } \\
\text { needed treatment }\end{array}$ & $\begin{array}{l}\text { The presence of mild atopic } \\
\text { asthma phenotypes, main- } \\
\text { ly differentiated by a family } \\
\text { history of asthma. }\end{array}$ \\
\hline Lee et al. ${ }^{40)}(2017)$ & 235 & LCA & 4 & $\begin{array}{l}\text { Atopy, lung function, } \\
\text { onset age, socioe- } \\
\text { conomic status, fre- } \\
\text { quency of asthma } \\
\text { exacerbation }\end{array}$ & $\begin{array}{l}\text { 1. High prevalence of atopy and mild symptoms } \\
\text { 2. Less atopy and normal lung function, but } \\
\text { intermittent troublesome asthma } \\
\text { 3. Late-onset atopic troublesome asthma with } \\
\text { decreased lung function with low socioeco- } \\
\text { nomic status } \\
\text { 4. Early-onset and less-atopic infrequent asthma }\end{array}$ & $\begin{array}{l}\text { Environmental factors might } \\
\text { be implicated in the clinical } \\
\text { heterogeneity of asthma. }\end{array}$ \\
\hline $\begin{array}{l}\text { Schatz et al. } \\
\quad(2014)\end{array}$ & $\begin{array}{l}518 \text { children } \\
\text { aged } 6-11 \\
\text { years, } 3,612 \\
\text { adolescents } \\
\text { and adults } \\
\text { ages } \geq 12 \\
\text { years }\end{array}$ & $\begin{array}{l}\text { Ward's minimum } \\
\text { variance me- } \\
\text { thod }\end{array}$ & 5 & $\begin{array}{l}\text { Sex, atopic status, } \\
\text { race, passive smoke } \\
\text { exposure, aspirin } \\
\text { sensitivity }\end{array}$ & $\begin{array}{l}<5 \text { clusters in children aged } 6-11 \text { years }> \\
\text { 1. Atopic white male patients with no smoke } \\
\text { exposure } \\
\text { 2. Atopic white female patients with no smoke } \\
\text { exposure } \\
\text { 3. Nonatopic status } \\
\text { 4. Passive smoke exposure } \\
\text { 5. Nonwhite race } \\
<5 \text { clusters in adolescents and adults ages } \geq 12 \\
\text { years }> \\
\text { 1. White female patients with adult onset, without } \\
\text { aspirin sensitivity and lower levels of total } \\
\text { serum lgE } \\
\text { 2. Highest atopy with atopic dermatitis } \\
\text { 3. Male sex } \\
\text { 4. Nonwhite race } \\
\text { 5. Aspirin sensitivity }\end{array}$ & $\begin{array}{l}\text { Distinct phenotypes appear to } \\
\text { exist in patients with severe } \\
\text { or difficult-to-treat asthma, } \\
\text { which is related to outcomes } \\
\text { in adolescents and adults but } \\
\text { not in children. }\end{array}$ \\
\hline $\begin{array}{l}\text { Savenije et al. }{ }^{30)} \\
(2011)\end{array}$ & 2,810 & LLCA & 5 & $\begin{array}{l}\text { Onset age, persis- } \\
\text { tence }\end{array}$ & $\begin{array}{l}\text { 1. Never/infrequent wheeze } \\
\text { 2. Transient early wheeze } \\
\text { 3. Intermediate-onset wheeze } \\
\text { 4. Late-onset wheeze } \\
\text { 5. Persistent wheeze }\end{array}$ & $\begin{array}{l}\text { An intermediate-onset pheno- } \\
\text { type with onset of wheeze } \\
\text { after } 2 \text { years of age is pre- } \\
\text { sent. }\end{array}$ \\
\hline $\begin{array}{l}\text { Henderson et al. }{ }^{31)} \\
\text { (2008) }\end{array}$ & 6,265 & LLCA & 6 & $\begin{array}{l}\text { Onset age, persis- } \\
\text { tence }\end{array}$ & $\begin{array}{l}\text { 1. Never/infrequent wheeze } \\
\text { 2. Transient early wheeze } \\
\text { 3. Prolonged early wheezing } \\
\text { 4. Intermediate-onset wheezing } \\
\text { 5. Late-onset wheezing } \\
\text { 6. Persistent wheezing }\end{array}$ & $\begin{array}{l}\text { The wheezing phenotypes } \\
\text { most strongly associated with } \\
\text { atopy and airway responsive- } \\
\text { ness were characterized by } \\
\text { onset after age } 18 \text { months. }\end{array}$ \\
\hline $\begin{array}{l}\text { Martinez et al. }{ }^{28)} \\
\text { (1995) }\end{array}$ & 826 & $\begin{array}{l}\text { Artificial classi- } \\
\text { fication accord- } \\
\text { ing to history } \\
\text { of wheezing at } \\
\text { ages } 3 \text { and } 6\end{array}$ & 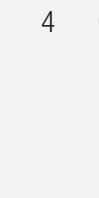 & $\begin{array}{l}\text { Onset age, persis- } \\
\text { tence }\end{array}$ & $\begin{array}{l}\text { 1. Never wheeze } \\
\text { 2. Early transient wheeze } \\
\text { 3. Persistent wheeze } \\
\text { 4. Late-onset wheeze }\end{array}$ & $\begin{array}{l}\text { There is a stronger positive } \\
\text { association between personal } \\
\text { history of eczema or allergic } \\
\text { rhinitis and persistent and } \\
\text { late-onset wheezing than } \\
\text { transient early wheezing. }\end{array}$ \\
\hline
\end{tabular}

LCA, latent class analysis; LLCA, longitudinal latent class analysis.

philic, neutrophilic, mixed granulocytic, and paucigranulocytic); ${ }^{32)}$ severe asthma phenotypes; ${ }^{33-36)}$ and diverse phenotypes encompassing asthma control status and diverse biomarkers, such as levels of exhaled nitric oxide and blood eosinophils, lung function, and cytokines. ${ }^{33,37)}$ Among the diverse variables used to classify asthma clusters, onset age of asthma or wheezing, sex, and atopy have been consistently included as important differential features. ${ }^{38)}$

The application of asthma phenotypes that originated from foreign countries to Korean children requires further validation since race affects asthma phenotypes..$^{39)}$ In an asthma phenotype study of Korean school-aged children using latent class analysis, 4 phenotypes were identified: high prevalence of atopy with mild symptoms, less atopy and normal lung function but intermittent troublesome asthma, late-onset atopic troublesome asthma with decreased lung function combined with low socioeconomic status, and early-onset and less-atopic infrequent asthma. ${ }^{40)}$ Socioeconomic factors might contribute to the development and prognosis of asthma through the microbiome and its related immune responses. ${ }^{41)}$ 
Table 3. Summary of representative phenotype studies of rhinitis

\begin{tabular}{|c|c|c|c|c|c|}
\hline Study & $\begin{array}{l}\text { Subject } \\
\text { number }\end{array}$ & $\begin{array}{l}\text { Methods of phenotypes } \\
\text { classification }\end{array}$ & $\begin{array}{l}\text { No. of } \\
\text { groups }\end{array}$ & Differential features & Main findings \\
\hline $\begin{array}{l}\text { Togias et al. }{ }^{47)} \\
\text { (2018) }\end{array}$ & 619 & Clinical classification & 5 & $\begin{array}{l}\text { 1. SAR } \\
\text { 2. PAR } \\
\text { 3. PAR with seasonal exacerbations } \\
\text { 4. Indeterminate AR } \\
\text { 5. Non-AR }\end{array}$ & $\begin{array}{l}\text { PAR with seasonal exacerbations: most } \\
\text { severe, associated with difficult-to- } \\
\text { control asthma }\end{array}$ \\
\hline Lee et al. ${ }^{42)}(2016)$ & 512 & LCA & 4 & $\begin{array}{l}\text { 1. Nonatopy \& low socioeconomic status } \\
\text { 2. High-atopic burden but normal lung function } \\
\text { 3. High-atopic burden and impaired lung function } \\
\text { 4. Low atopy and a high socioeconomic status }\end{array}$ & $\begin{array}{l}\text { Rhinitis with atopy and impaired lung } \\
\text { function: associated with allergic march }\end{array}$ \\
\hline $\begin{array}{l}\text { Kurukulaaratchy, } \\
\text { et al. }{ }^{46)}(2015)\end{array}$ & 1,456 & Cluster analysis & 4 & $\begin{array}{l}\text { 1. Moderate childhood onset rhinitis } \\
\text { 2. Mild adolescence-onset female rhinitis } \\
\text { 3. Severe earliest-onset rhinitis with asthma } \\
\text { 4. Moderate childhood onset male rhinitis with asthma }\end{array}$ & $\begin{array}{l}\text { Moderate childhood-onset male rhinitis } \\
\text { with asthma: high atopy, intermediate } \\
\text { asthma, low eczema }\end{array}$ \\
\hline $\begin{array}{l}\text { Khanna et al. } \\
\text { (2005) }\end{array}$ & 114 & $\begin{array}{l}\text { Artificial classification ac- } \\
\text { cording to main symp- } \\
\text { toms }\end{array}$ & 2 & $\begin{array}{l}\text { 1. Sneezers and runners } \\
\text { 2. Blockers }\end{array}$ & $\begin{array}{l}\text { Sneezers and runners: associated with } \\
\text { SAR and moderate to severe intermit- } \\
\text { tent disease } \\
\text { Blockers: associated with mild persistent }\end{array}$ \\
\hline
\end{tabular}

AR, allergic rhinitis; LCA, latent class analysis; PAR, perennial allergic rhinitis; SAR, seasonal allergic rhinitis.

Although phenotype studies have contributed to increasing our understanding of the pathophysiology of asthma and wheezing in children, there are some limitations to the application of the diverse phenotypes in clinical practice due to the heterogeneous characteristics of asthma. A multidisciplinary approach including molecular phenotypes, biomarkers, and clinical markers might allow the identification of asthma and wheezing phenotypes in children worldwide, thereby contributing to improvements in personalized care in children with asthma.

\section{Phenotypes of AR in children}

Although AR is common, accounting for approximately 30\%$40 \%$ of children, its effect on quality of life is substantial, ${ }^{42)}$ while concerns regarding AR have received less attention. Therefore, studies of AR phenotypes are relatively lacking compared with other allergic diseases. Rhinitis is conventionally classified into AR, infectious rhinitis, and nonallergic and noninfectious rhinitis, with combinations of more than 2 types in some cases. The initial classification of AR included seasonal AR and perennial AR (PAR) based on symptom timing and triggering allergens. ${ }^{43}$ In the 2001 revision of Allergic Rhinitis and its Impact on Asthma, ${ }^{44)}$ the terms "duration" and "severity" were introduced due to the considerable impact of AR on quality of life. The classification of AR based on duration (intermittent vs. persistent), severity, and its impact on quality of life (mild or moderate vs. severe) is helpful for the selection of optimal treatment. ${ }^{45}$

However, these classifications had limited ability to explain the underlying pathophysiology and predict AR prognosis. The subsequent diverse studies on AR phenotypes used unsupervised cluster analysis methods without observer bias to better reflect the heteroge- neity of AR. ${ }^{42,46}$ Sensitization patterns, comorbidities, and treatment responses in AR are important differential features for classifying AR phenotypes (Table 3). ${ }^{42,47)}$ AR phenotypes can be classified according to the underlying pathophysiologic features, such as high Th2 immune responses, which might be associated with treatment responses. ${ }^{42)}$

A recent study of AR classification in children with asthma showed that PAR with seasonal exacerbations was the most common type and was associated with difficult-to-control asthma, ${ }^{47)}$ suggesting a linked airway disease of AR and asthma. In a cohort study followed up from birth to 18 years of age, rhinitis was classified based on sex, severity, onset age, and comorbidities into the following 4 phenotypes: moderate childhood-onset rhinitis, mild adolescent-onset female rhinitis, severe earliest-onset rhinitis with asthma, and moderate childhood-onset male rhinitis with asthma. ${ }^{46)}$ This study suggested that more severe and earlier-onset rhinitis was associated with asthma. ${ }^{46)}$ In another study in school-aged children in Korea, ${ }^{42)}$ a latent class analysis considering sex, body mass index, socioeconomic status, exposure to environmental tobacco smoke, and parental history of allergic diseases revealed the following 4 phenotypes: nonatopy and low socioeconomic status, high-atopic burden but normal lung function, high-atopic burden and impaired lung function, and lowatopic burden and high socioeconomic status. In that study, children with rhinitis in the high-atopic burden and impaired lung function group exhibited an increased risk of allergic march. ${ }^{42)}$

As such, studies on AR phenotypes have identified the association between asthma prognosis and AR severity and comorbidities. This might be associated with the need for early intervention to prevent comorbidities in high-risk individuals. Studies on rhinitis phenotypes have even considered biomarkers, enabling the development of more effective treatments and individualized management. The ultimate goal of studies of AR phenotypes is developing the ability 
to suggest the appropriate treatment for individuals and develop therapeutics for each phenotype, thereby improving quality of life with the introduction of personalized medicine.

\section{Phenotypes of atopy}

Sensitization may be among the most important features that can be used to classify the important heterogeneous allergic diseases and explain the mechanisms underlying their diverse phenotypes. Concomitant allergic sensitization also affects the risk of comorbidities in children with allergic diseases. ${ }^{48)}$ Phenotypes of sensitization are classified depending on sensitized allergen types, number of allergens, severity of sensitization, and changing patterns in sensitization during follow-up. ${ }^{49-53)}$ Since age at sensitization to specific allergens affects the association between sensitization and allergic diseases, ${ }^{54)}$ assessing sensitization merely at one time point at a specific age cannot fully explain the association between sensitization and allergic diseases or their prognosis. ${ }^{51,55)}$ In addition, sensitization patterns change with age; therefore, the associations between sensitization in early life and allergic diseases might be too weak to define the endotype. ${ }^{54)}$ Therefore, identifying sensitization phenotypes over a long period and their correlation with clinical outcomes may provide information about the complex association between atopy and allergic diseases and may ultimately help predict the prognosis of allergic diseases and establish prevention strategies for children with them.

In the beginning phase of atopy phenotype studies, sensitization patterns were classified according to sensitized allergens (dust mite vs. nondust mite), number of sensitizations (mono-sensitization vs.

Table 4. Summary of representative atopy phenotype studies

\begin{tabular}{|c|c|c|c|c|}
\hline Study & Subject number & $\begin{array}{l}\text { Methods of } \\
\text { phenotype } \\
\text { classification }\end{array}$ & $\begin{array}{l}\text { No. of } \\
\text { groups }\end{array}$ & Characteristics of phenotypes \\
\hline $\begin{array}{l}\text { Dharma et al. } \\
\text { (2018) }\end{array}$ & 2,629 & LCA & 5 & $\begin{array}{l}\text { 1. Healthy } \\
\text { 2. Atopic dermatitis } \\
\text { 3. Inhalant sensitization } \\
\text { 4. Transient sensitization } \\
\text { 5. Persistent sensitization }\end{array}$ \\
\hline
\end{tabular}

\begin{tabular}{|c|c|c|c|c|c|}
\hline $\begin{array}{l}\text { Schoos et al. }{ }^{51)} \\
(2017)\end{array}$ & 398 & $\begin{array}{l}\text { NNS-PARAFAC } \\
\text { model }\end{array}$ & 7 & $\begin{array}{l}\text { 1. Dog/cat/horse } \\
\text { 2. Timothy grass/birch } \\
\text { 3. Molds } \\
\text { 4. House dust mites } \\
\text { 5. Peanut/wheat flour/mugwort } \\
\text { 6. Peanut/soybean } \\
\text { 7. Egg/milk/wheat flour }\end{array}$ & $\begin{array}{l}\text { Asthma: associated with pattern } 1 \\
\text { Rhinitis: associated with patterns } 1-4 \text { and } 6 \\
\text { Eczema: patterns } 1-3 \text { and } 5-7\end{array}$ \\
\hline $\begin{array}{l}\text { Lee et al. }{ }^{49)} \\
(2017)\end{array}$ & 616 & LCA & 4 & $\begin{array}{l}\text { 1. Later sensitization to indoor allergens } \\
\text { 2. Multiple early sensitization } \\
\text { 3. Early sensitization to outdoor allergens, especially } \\
\text { Alternaria, and later sensitization to indoor allergens, } \\
\text { including Aspergillus } \\
\text { 4. Early sensitization to indoor allergens and later sensi- } \\
\text { tization to outdoor allergens }\end{array}$ & $\begin{array}{l}\text { Early sensitization to outdoor allergens and } \\
\text { later sensitization to indoor allergens: } \\
\text { associated with risk of new-onset bronchial } \\
\text { hyper-responsiveness }\end{array}$ \\
\hline $\begin{array}{l}\text { Havstad et al. }^{50)} \\
(2014)\end{array}$ & 399 & $\begin{array}{l}\text { Latent class } \\
\text { model }\end{array}$ & 4 & $\begin{array}{l}\text { 1. Low to no sensitization } \\
\text { 2. Highly sensitized } \\
\text { 3. Milk and egg dominated } \\
\text { 4. Peanut and inhalant }\end{array}$ & $\begin{array}{l}\text { Highly sensitized group: associated with a } \\
\text { doctor's diagnosis of asthma after the age } \\
\text { of } 4 \text { years }\end{array}$ \\
\hline $\begin{array}{l}\text { Lazic et al. }{ }^{61)} \\
(2013)\end{array}$ & $\begin{array}{c}\text { MAAS }(n=1,028) \\
\quad \operatorname{loW}(n=1,226)\end{array}$ & $\begin{array}{l}\text { Hidden Markov } \\
\text { model }\end{array}$ & 5 & $\begin{array}{l}\text { 1. Few or no positive tests } \\
\text { 2. Early childhood sensitivity to grass pollens and transient } \\
\text { sensitivity to eggs, but not to mite } \\
\text { 3. Sensitivity to mite, but rarely to other allergens } \\
\text { 4. Early sensitivity to mite, grass, and tree pollens, later } \\
\text { onset of sensitivity to pets } \\
\text { 5. Sensitivity to a wide variety of allergens, including mite, } \\
\text { pollens, cat and dog, throughout childhood }\end{array}$ & $\begin{array}{l}\text { Sensitivity to a wide variety of allergens: } \\
\text { much more likely to have asthma }\end{array}$ \\
\hline $\begin{array}{l}\text { Simpson et al. }{ }^{55)} \\
(2010)\end{array}$ & 1,053 & $\begin{array}{l}\text { Hidden Markov } \\
\text { model }\end{array}$ & 5 & $\begin{array}{l}\text { 1. No latent atopic vulnerability } \\
\text { 2. Nondust mite } \\
\text { 3. Dust mite } \\
\text { 4. Multiple late } \\
\text { 5. Multiple early }\end{array}$ & $\begin{array}{l}\text { Multiple early: associated with development } \\
\text { of asthma, poorer lung function and airway } \\
\text { reactivity, increase in risk of hospital ad- } \\
\text { mission for asthma }\end{array}$ \\
\hline
\end{tabular}

IoW, islet of wight; LCA, latent class analysis; MAAS, Manchester Asthma and Allergy Study; NNS-PARAFAC, NonNegative Sparse PARAllel FACtor analysis. 
multiple sensitizations), and sensitization period (early vs. late). ${ }^{52,56,57)}$ These studies provide important information about the associations between sensitization patterns and prognosis of allergic diseases. ${ }^{48,55)}$ However, these studies have limited ability to explain the mechanisms underlying each phenotype of atopy and the heterogeneous spectra of allergic diseases. Subsequent studies have reported diverse atopy phenotypes encompassing more subdivided patterns and considered changes in sensitization patterns over a long-term period using unsupervised methods to decrease possible bias (Table 4). ${ }^{49)}$ Studies considering the association between allergen sensitization, especially during early life, allergen exposure periods, including the perinatal periods, and allergic diseases might provide additional information about these associations and disease prognosis. This might better reflect the complex interactions of sensitization with allergic diseases and underlying pathophysiology. ${ }^{49-51)}$

The sensitization status is unstable, especially in early life; therefore, the consideration of temporal changes in sensitization is essential to applying the atopy phenotypes in clinical practice. ${ }^{48)}$ For example, the persistent sensitization from 1 year to 3 years is associated with an increased risk of allergic diseases, including $A R, A D$, and asthma, whereas transient sensitization at 1 year of age is associated with an increased risk of food allergy only. ${ }^{58)}$ Early sensitization to outdoor allergens and later sensitization to indoor allergens in school-aged children was associated with an increased risk of bronchial hyperresponsiveness. ${ }^{49)}$

However, the assessment of chronologic changes in sensitization itself might have limited ability to assess the association between sensitization patterns and allergic diseases. ${ }^{54)}$ Simultaneous consideration of the combined allergic diseases might better explain the complex association between sensitization and allergic diseases and enable better prediction of the prognosis of allergic diseases ${ }^{48}{ }^{48}$ Future studies are needed on atopy phenotypes considering the diverse factors in children followed up until adulthood and their association with an exposure period to specific allergens. Further validation of whether the atopy phenotypes established in other countries can be applied to Korean children despite the differences in ethnicities is needed.

\section{Future perspective}

Previous studies have identified diverse phenotypes in each allergic disease and atopy. In the future, the identification of phenotypes that consider disease heterogeneity with regard to the genetic and exposed environmental aspects, including the perinatal period, and lifestyle changes, combined with the underlying pathogenesis, is needed. The clinical features and related immunopathophysiologies as well as long-term prognosis of each phenotype of allergic diseases might differ among ethnicities. ${ }^{59)}$ Therefore, phenotypes in allergic diseases that can be globally applied should consider the different factors according to ethnicity. Furthermore, phenotypes defined considering changes over time with regard to the pathophysiologies and immunologies, termed endotypes, might be helpful for completely understanding each phenotype of diverse allergic diseases. Research on phenotypes of allergic diseases, especially in birth cohort studies or longitudinal prospective studies, would be helpful for identifying the characteristics of each phenotype in an individual's lifespan. Ultimately, integrated approaches including omics technology based on phenotypes of allergic diseases may be useful in developing personalized medicine and precision medicine in the future.

\section{Conclusions}

Many phenotype studies on allergic diseases using diverse methods from artificial classification to less biased machine learning approaches are available. These approaches enable better identification of the characterization of heterogeneous allergic diseases and the underlying pathophysiology of diverse allergic diseases. The differential features include clinical factors and diverse biomarkers, such as onset age, main inflammation type, persistency, severity, and comorbidities. However, these studies have limited ability to fully explain the heterogeneous diverse phenotypes of allergic diseases. In addition, the extrapolation of various phenotypes of allergic diseases in foreign countries to Korean children requires validation because of ethnicity differences. The recent approaches to phenotype classification of allergic diseases using multiple omics technologies facilitate investigations on the underlying pathophysiology of heterogeneous allergic diseases and development of personalized medicine, which are the ultimate goals of phenotype classification.

\section{Conflicts of interest}

No potential conflict of interest relevant to this article was reported.

\section{Acknowledgments}

This study was financially supported by Chonnam National University.

\section{References}

1. Bieber T. Atopic dermatitis 2.0: from the clinical phenotype to the molecular taxonomy and stratified medicine. Allergy 2012;67:147582.

2. Giavina-Bianchi P. Defining phenotypes in rhinitis: a step toward 
personalized medicine. J Allergy Clin Immunol 2015;135:151-2.

3. Bieber T, D'Erme AM, Akdis CA, Traidl-Hoffmann C, Lauener R, Schäppi G, et al. Clinical phenotypes and endophenotypes of atopic dermatitis: where are we, and where should we go? J Allergy Clin Immunol 2017;139(4S):S58-64.

4. Vidotto D, Vermunt JK, van Deun K. Bayesian multilevel latent class models for the multiple imputation of nested categorical data. J Educ Behav Stat 2018;43:511-39.

5. Williams HC, Strachan DP. The natural history of childhood eczema: observations from the British 1958 birth cohort study. Br J Dermatol 1998;139:834-9.

6. Tokura Y. Extrinsic and intrinsic types of atopic dermatitis. J Dermatol Sci 2010;58:1-7.

7. Pugliarello S, Cozzi A, Gisondi P, Girolomoni G. Phenotypes of atopic dermatitis. J Dtsch Dermatol Ges 2011;9:12-20.

8. Suárez-Fariñas M, Dhingra N, Gittler J, Shemer A, Cardinale I, de Guzman Strong C, et al. Intrinsic atopic dermatitis shows similar TH2 and higher TH17 immune activation compared with extrinsic atopic dermatitis. J Allergy Clin Immunol 2013;132:361-70.

9. Weidinger S, Novak N. Atopic dermatitis. Lancet 2016;387:1109-22.

10. Esaki H, Brunner PM, Renert-Yuval Y, Czarnowicki T, Huynh T, Tran $\mathrm{G}$, et al. Early-onset pediatric atopic dermatitis is TH2 but also TH17 polarized in skin. J Allergy Clin Immunol 2016;138:1639-51.

11. Czarnowicki T, Esaki H, Gonzalez J, Malajian D, Shemer A, Noda S, et al. Early pediatric atopic dermatitis shows only a cutaneous lymphocyte antigen (CLA)(+) TH2/TH1 cell imbalance, whereas adults acquire CLA(+) TH22/TC22 cell subsets. J Allergy Clin Immunol 2015;136: 941-51.e3.

12. Paternoster L, Savenije OEM, Heron J, Evans DM, Vonk JM, Brunekreef $\mathrm{B}$, et al. Identification of atopic dermatitis subgroups in children from 2 longitudinal birth cohorts. J Allergy Clin Immunol 2018;141: 964-71.

13. Czarnowicki T, Gonzalez J, Shemer A, Malajian D, Xu H, Zheng X, et al. Severe atopic dermatitis is characterized by selective expansion of circulating TH2/TC2 and TH22/TC22, but not TH17/TC17, cells within the skin-homing T-cell population. J Allergy Clin Immunol 2015; 136:104-15.e7.

14. Farrell AM, Antrobus P, Simpson D, Powell S, Chapel HM, Ferry BL. A rapid flow cytometric assay to detect CD4+ and CD8+ T-helper (Th) 0, Th1 and Th2 cells in whole blood and its application to study cytokine levels in atopic dermatitis before and after cyclosporin therapy. Br J Dermatol 2001;144:24-33.

15. Amat F, Saint-Pierre P, Bourrat E, Nemni A, Couderc R, BoutmyDeslandes E, et al. Early-onset atopic dermatitis in children: which are the phenotypes at risk of asthma? Results from the ORCA cohort. PLoS One 2015;10:e0131369.

16. Roduit C, Frei R, Depner M, Karvonen AM, Renz H, Braun-Fahrländer C, et al. Phenotypes of atopic dermatitis depending on the timing of onset and progression in childhood. JAMA Pediatr 2017;171:655-62.

17. Lee E, Lee SH, Kwon JW, Kim YH, Cho HJ, Yang SI, et al. Atopic dermatitis phenotype with early onset and high serum IL-13 is linked to the new development of bronchial hyperresponsiveness in school children. Allergy 2016;71:692-700.

18. Seo E, Yoon J, Jung S, Lee J, Lee BH, Yu J. Phenotypes of atopic dermatitis identified by cluster analysis in early childhood. J Dermatol 2019;46:117-23.

19. Burgess JA, Dharmage SC, Byrnes GB, Matheson MC, Gurrin LC, Wharton CL, et al. Childhood eczema and asthma incidence and persistence: a cohort study from childhood to middle age. J Allergy Clin Immunol 2008;122:280-5.

20. Bass AM, Anderson KL, Feldman SR. Interventions to increase treatment adherence in pediatric atopic dermatitis: a systematic review. J Clin Med 2015;4:231-42.
21. Irvine $A D$, McLean WH, Leung DY. Filaggrin mutations associated with skin and allergic diseases. N Engl J Med 2011;365:1315-27.

22. Kabesch M, Carr D, Weiland SK, von Mutius E. Association between polymorphisms in serine protease inhibitor, kazal type 5 and asthma phenotypes in a large German population sample. Clin Exp Allergy 2004;34:340-5.

23. Ahmad-Nejad P, Mrabet-Dahbi S, Breuer K, Klotz M, Werfel T, Herz U, et al. The toll-like receptor $2 \mathrm{R} 753 \mathrm{Q}$ polymorphism defines a subgroup of patients with atopic dermatitis having severe phenotype. J Allergy Clin Immunol 2004;113:565-7.

24. Noda S, Suárez-Fariñas M, Ungar B, Kim SJ, de Guzman Strong C, Xu $\mathrm{H}$, et al. The Asian atopic dermatitis phenotype combines features of atopic dermatitis and psoriasis with increased TH17 polarization. J Allergy Clin Immunol 2015;136:1254-64.

25. Cowan K, Guilbert TW. Pediatric asthma phenotypes. Curr Opin Pediatr 2012;24:344-51.

26. Rackemann FM. A working classification of asthma. Am J Med 1947; 3:601-6.

27. Walker C, Bode E, Boer L, Hansel TT, Blaser K, Virchow JC Jr. Allergic and nonallergic asthmatics have distinct patterns of T-cell activation and cytokine production in peripheral blood and bronchoalveolar lavage. Am Rev Respir Dis 1992;146:109-15.

28. Martinez FD, Wright AL, Taussig LM, Holberg CJ, Halonen M, Morgan WJ. Asthma and wheezing in the first six years of life. The Group Health Medical Associates. N Engl J Med 1995;332:133-8.

29. Rusconi F, Galassi C, Corbo GM, Forastiere F, Biggeri A, Ciccone G, et al. Risk factors for early, persistent, and late-onset wheezing in young children. SIDRIA Collaborative Group. Am J Respir Crit Care Med 1999;160(5 Pt 1):1617-22.

30. Savenije OE, Granell R, Caudri D, Koppelman GH, Smit HA, Wijga A, et al. Comparison of childhood wheezing phenotypes in 2 birth cohorts: ALSPAC and PIAMA. J Allergy Clin Immunol 2011;127:1505-12.e14.

31. Henderson J, Granell R, Heron J, Sherriff A, Simpson A, Woodcock A, et al. Associations of wheezing phenotypes in the first 6 years of life with atopy, lung function and airway responsiveness in mid-childhood. Thorax 2008;63:974-80.

32. Ordoñez CL, Shaughnessy TE, Matthay MA, Fahy JV. Increased neutrophil numbers and IL-8 levels in airway secretions in acute severe asthma: Clinical and biologic significance. Am J Respir Crit Care Med 2000;161(4 Pt 1):1185-90.

33. Fitzpatrick AM, Moore WC. Severe asthma phenotypes - how should they guide evaluation and treatment? J Allergy Clin Immunol Pract 2017;5:901-8.

34. Denlinger LC, Phillips BR, Ramratnam S, Ross K, Bhakta NR, Cardet JC, et al. Inflammatory and comorbid features of patients with severe asthma and frequent exacerbations. Am J Respir Crit Care Med 2017; 195:302-13.

35. Sorkness RL, Teague WG, Penugonda M, Fitzpatrick AM; National Institutes of Health, National Heart, Lung, and Blood Institute's Severe Asthma Research Program. Sex dependence of airflow limitation and air trapping in children with severe asthma. J Allergy Clin Immunol 2011;127:1073-4.

36. Sendín-Hernández MP, Ávila-Zarza C, Sanz C, García-Sánchez A, Marcos-Vadillo E, Muñoz-Bellido FJ, et al. Cluster analysis identifies 3 phenotypes within allergic asthma. J Allergy Clin Immunol Pract 2018;6:955-61.e1.

37. Terl M, Sedlák V, Cap P, Dvořáková R, Kašák V, Kočí T, et al. Asthma management: a new phenotype-based approach using presence of eosinophilia and allergy. Allergy 2017;72:1279-87.

38. Desai M, Oppenheimer J. Elucidating asthma phenotypes and endotypes: progress towards personalized medicine. Ann Allergy Asthma Immunol 2016;116:394-401. 
39. Schatz M, Hsu JW, Zeiger RS, Chen W, Dorenbaum A, Chipps BE, et al. Phenotypes determined by cluster analysis in severe or difficult-totreat asthma. J Allergy Clin Immunol 2014;133:1549-56.

40. Lee E, Lee SH, Kwon JW, Kim YH, Yoon J, Cho HJ, et al. Persistent asthma phenotype related with late-onset, high atopy, and low socioeconomic status in school-aged Korean children. BMC Pulm Med 2017;17:45.

41. Kim BJ, Lee SY, Kim HB, Lee E, Hong SJ. Environmental changes, microbiota, and allergic diseases. Allergy Asthma Immunol Res 2014; 6:389-400.

42. Lee E, Lee SH, Kwon JW, Kim Y, Cho HJ, Yang SI, et al. A rhinitis phenotype associated with increased development of bronchial hyperresponsiveness and asthma in children. Ann Allergy Asthma Immunol 2016;117:21-8.e1.

43. Brożek JL, Bousquet J, Agache I, Agarwal A, Bachert C, Bosnic-Anticevich S, et al. Allergic Rhinitis and its Impact on Asthma (ARIA) guidelines-2016 revision. J Allergy Clin Immunol 2017;140:950-8.

44. Bousquet J, Van Cauwenberge P, Khaltaev N; Aria Workshop Group; World Health Organization. Allergic rhinitis and its impact on asthma. J Allergy Clin Immunol 2001;108(5 Suppl):S147-334.

45. Papadopoulos NG, Bernstein JA, Demoly P, Dykewicz M, Fokkens W, Hellings PW, et al. Phenotypes and endotypes of rhinitis and their impact on management: a PRACTALL report. Allergy 2015;70:47494.

46. Kurukulaaratchy RJ, Zhang H, Patil V, Raza A, Karmaus W, Ewart S, et al. Identifying the heterogeneity of young adult rhinitis through cluster analysis in the Isle of Wight birth cohort. J Allergy Clin Immunol 2015;135:143-50.

47. Togias A, Gergen PJ, Hu JW, Babineau DC, Wood RA, Cohen RT, et al. Rhinitis in children and adolescents with asthma: Ubiquitous, difficult to control, and associated with asthma outcomes. J Allergy Clin Immunol 2019;143:1003-11.e10.

48. Tran MM, Lefebvre DL, Dharma C, Dai D, Lou WYW, Subbarao P, et al. Predicting the atopic march: Results from the Canadian Healthy Infant Longitudinal Development Study. J Allergy Clin Immunol 2018;141:601-7.e8.

49. Lee E, Lee SH, Kim YH, Cho HJ, Yoon J, Yang SI, et al. Association of atopy phenotypes with new development of asthma and bronchial hyperresponsiveness in school-aged children. Ann Allergy Asthma Immunol 2017;118:542-50.e1.
50. Havstad S, Johnson CC, Kim H, Levin AM, Zoratti EM, Joseph CL, et al. Atopic phenotypes identified with latent class analyses at age 2 years. J Allergy Clin Immunol 2014;134:722-7.e2.

51. Schoos AM, Chawes BL, Melén E, Bergström A, Kull I, Wickman M, et al. Sensitization trajectories in childhood revealed by using a cluster analysis. J Allergy Clin Immunol 2017;140:1693-9.

52. Boulet LP, Turcotte H, Laprise C, Lavertu C, Bédard PM, Lavoie A, et al. Comparative degree and type of sensitization to common indoor and outdoor allergens in subjects with allergic rhinitis and/or asthma. Clin Exp Allergy 1997;27:52-9.

53. Huss K, Adkinson NF Jr, Eggleston PA, Dawson C, Van Natta ML, Hamilton RG. House dust mite and cockroach exposure are strong risk factors for positive allergy skin test responses in the Childhood Asthma Management Program. J Allergy Clin Immunol 2001;107:4854.

54. Schoos AM, Chawes BL, Rasmussen MA, Bloch J, Bønnelykke K, Bisgaard H. Atopic endotype in childhood. J Allergy Clin Immunol 2016;137:844-51.e4.

55. Simpson A, Tan VY, Winn J, Svensén M, Bishop CM, Heckerman DE, et al. Beyond atopy: multiple patterns of sensitization in relation to asthma in a birth cohort study. Am J Respir Crit Care Med 2010;181: 1200-6.

56. von Mutius E, Martinez FD, Fritzsch C, Nicolai T, Roell G, Thiemann HH. Prevalence of asthma and atopy in two areas of West and East Germany. Am J Respir Crit Care Med 1994;149(2 Pt 1):358-64.

57. Arshad SH, Tariq SM, Matthews S, Hakim E. Sensitization to common allergens and its association with allergic disorders at age 4 years: a whole population birth cohort study. Pediatrics 2001;108:E33.

58. Dharma C, Lefebvre DL, Tran MM, Lou WYW, Subbarao P, Becker AB, et al. Patterns of allergic sensitization and atopic dermatitis from 1 to 3 years: Effects on allergic diseases. Clin Exp Allergy 2018;48:48-59.

59. Czarnowicki T, He H, Krueger JG, Guttman-Yassky E. Atopic dermatitis endotypes and implications for targeted therapeutics. J Allergy Clin Immunol 2019;143:1-11.

60. Khanna P, Shah A. Categorization of patients with allergic rhinitis: a comparative profile of "sneezers and runners" and "blockers". Ann Allergy Asthma Immunol 2005;94:60-4.

61. Lazic N, Roberts G, Custovic A, Belgrave D, Bishop CM, Winn J, et al. Multiple atopy phenotypes and their associations with asthma: similar findings from two birth cohorts. Allergy 2013;68:764-70. 